\title{
The Effect of a Nurse Education Program on Infiltration and Extravasation in Pediatric Patients at a University Hospital
}

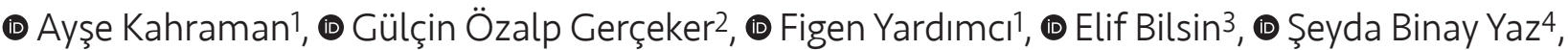 \\ (1) Hamide Nur Çevik Özdemir5, (1) Atiye Karakul6, (1) Dilek Zengin1, (1) Seda Ardahan Sevgili1, \\ (1) Merve Gümüş ${ }^{1}$, (1) Selma Akpınar7, (1) Didar Zümrüt Başbakkal1 \\ ${ }^{1}$ Ege University Faculty of Nursing, Department of Pediatric Nursing, İzmir, Turkey \\ ${ }^{2}$ Dokuz Eylül University Faculty of Nursing, Department of Pediatric Nursing, İzmir, Turkey \\ ${ }^{3}$ Gaziantep University Faculty of Health Sciences, Department of Nursing, Gaziantep, Turkey \\ 4 izmir Bakırçay University Faculty of Health Sciences, Department of Nursing, İzmir, Turkey \\ ${ }^{5}$ Afyonkarahisar University Faculty of Health Sciences, Department of Nursing, Afyonkarahisar, Turkey \\ Gizmir Katip Çelebi University Faculty of Health Sciences, Department of Nursing, İzmir, Turkey \\ ${ }^{7}$ Ege University Children's Hospital, İzmir, Turkey
}

\begin{abstract}
Aim: Prevention of infiltration/extravasation (I/E) in pediatric patients is important. This study has examined the effect of an education program, which aims to prevent and manage pediatric I/E, on I/E rates in pediatric patients.

Materials and Methods: This is a semi-experimental study with a single group pre-test/post-test design. A sample of 79 nursing staff and $289 \mathrm{IV}$ catheters of 150 pediatric patients was investigated. Pediatric I/E training was given to the nurses and the effectiveness of the training program and $\mathrm{I} / \mathrm{E}$ rates before and after the training were evaluated.

Results: Compared to the pre-education phase, there was a significant increase in the mean scores of the nurses' knowledge in the posteducation phase $(t: 7,328 ; p<0.001)$. The education program was implemented based on the probability rate that was calculated by the researchers; this enabled a 12-fold reduction of pediatric I/E (odds ratio: $12,214,95 \%$ confidence interval).

Conclusion: This study has led to an improvement in nursing care, an improvement in the quality of patient care and has helped progress toward increased patient safety.
\end{abstract}

Keywords: Child, infiltration, extravasation, nurse education program, clinical education program

\section{Introduction}

Infiltration/extravasation (I/E) are the two mostcommon complications related to intravenous (IV) interventions (1,2). I involves leaking of the non-vesicant fluid into the tissue and $\mathrm{E}$ is the leakage of the vesicant medication or fluid into the tissue $(1,3,4)$. Tripi et al. (5) found I in $13 \%$ of catheters. Wilkins and Emmerson (6) found a $0.38 \%$ level of $E$ in their study. Temizsoy et al. (7) noted that the I rate was $32 \%$ and the $\mathrm{E}$ rate was $6 \%$. Atay et al. (8) found that $\mathrm{I} / \mathrm{E}$ occurred in $45.6 \%$ of newborns. Gerçeker et al. (9) stated that the I rate was $2.9 \%$ and the E rate was $2.3 \%$ in Turkey. 
I/E of fluids or medication is usually caused by the misplacement of the catheter or an increase in the permeability of the vein (10). Small and fragilevein structures, reduced peripheric circulation, capillary deficiency, and flexible tissues under the skin increase the risk of developing I/E in children (11).

Minor I's recover spontaneously within a short period. However, major I/E's in children lead to a loss of skin and tissue; disruption of comfort due to pain, infection, and malformation; muscle and tendon necrosis that requires plastic surgery or amputation; extended hospitalization; reductions in the satisfaction of patients and their families and importantly a decrease in the safety of patients; and an increase in morbidity and hospital costs $(1,2,12,13)$.

The role of the nurse is vital in reducing IV intervention complications and ensuring patient safety by applying their knowledge and skills to IV interventions $(2,14)$. Nurses are expected to diagnose early on in the procedure the symptoms and findings related to I/E and to act rapidly and effectively to reduce possible damage in tissues (14). The most important nursing intervention in $\mathrm{I} E \mathrm{E}$ is prevention. Previous studies have emphasized that the risk of I/E development is reduced through training nurses and more frequent observation of the I/E area (2). In studies conducted in different countries, it has been determined that the education given to nurses about pediatric I/E is effective $(2,13,15)$. At the same time, it is emphasized that it is important to repeat these trainings regularly and to develop education programs, education protocols and algorithms $(9,15)$. This study examined the effect of an education program that aimed to prevent and manage pediatric I/E on the subsequent I/E rates in pediatric patients.

\section{Materials and Methods}

This is a quasi-experimental study in a single group with a pre-test/post-test design. The study data were collected between February 2016 and September 2016. The researchers decided to launch the pediatric I/E education program based on the results of a previous study "I/E in Pediatric Patients: A Prevalence Study in a Children's Hospital" (9). The current education program was initiated with the preparation of an education program about the prevention and management of pediatric I/E. The researchers had planned to give this education program to all nurses in the hospital where the study was carried out; however, only 79 nurses (66\%) participated in the study. The researchers collected the relevant data from the pediatric patients on their I/E rate by monitoring 289 IV catheters in 150 patients during 1,221 patient days. The study sample included patients aged 18 years or younger (including newborns) who had IV catheters and were inpatients during monitoring. A power analysis was conducted based on the I/E rate determined. It showed that 270 catheters were needed to detect a 0.20 effect size using 0.80 power and a 0.05 significance level (16). This study was completed in six months. We included 289 catheters in the study, taking into account a $5 \%$ loss of sample.

\section{Data Collection}

A preliminary study was the basis of this study. In the previous study, the rates of I/E were high and faulty practices were performed (9). For this reason, we planned this pediatric I/E education program. The erroneous applications of I/E observed in the previous study, which directed the researcher to conduct the present study, proved the need to develop an urgent intervention in the prevention and management of pediatric I/E. These previous observations were the foundation of the pediatric I/E education program and the pediatric I/E education program was prepared subsequently. The pediatric I/E education program stage of the study was performed in February and March 2016. The pediatric I/E education program was delivered in five sessions so that most of the nurses in the relevant hospital could participate. However, the researchers managed to reach only $66 \%$ of the population. The effectiveness of the education program was evaluated using the "Pediatric I/E Prevention and Management Information Form" before and after the education program. The researchers also hung posters in the service areas of the hospitals about the education program content as a reminder to ensure the continuity of the knowledge provided to the participants. The researchers also anticipated that the posters would help the non-participant nurses as well to become more informed about the subject. Afterward, the researchers conducted a data collection stage focusing on the pediatric I/E rates and management after the education program.

In the framework of the study, all infants and children in all services and units of the pediatric hospital who were inpatients were monitored by the researchers. Before the study, all the researchers were trained about pediatric $I / E$, the education program, the forms and scales to be used. I was observed in only one patient after the training. Therefore, the harmony between the researchers was not examined. To collect data, the researchers used the IV Insertion Site in the Pediatric Patient Evaluation Form 
and the IV Insertion Site in the Pediatric Patients with I/E Evaluation Form, starting from the patient's admission to the hospital and the implantation of the catheter. Those patients who had IV catheters were monitored after an evaluation of their demographic characteristics, catheter insertion point, the purpose for the catheter, and intake of fluids and medication. The researchers conducted a regular daily follow-up of the patients, and evaluated them for the development of I/E in their catheters, the reason for removing the catheter if it was removed, and the presence of a new catheter. If there was I/E, the researchers determined its location; the fluid or medicine that was infiltrated or extravasated; the speed of its flow; the days passed after the implementation of the catheter until the I/E development as well as the period until its recognition; and any interventions/initiations. The researchers photographed the relevant area in those patients who developed I/E and determined its level with the assistance of the scales. The I/E rate was determined by calculating the number of I/Es divided by the total number of patient days (I/E number/ catheter days $\times 1,000$ ).

Pediatric infiltration and extravasation education program: The presentations in the pediatric I/E education program were prepared with the guidance of evidencebased studies as well as algorithms in the current literature $(1,16,17)$. The education program content included descriptions of pediatric $I / E$, risk factors and symptoms of $\mathrm{I} E$, the medications and fluid lists that have a greater risk for I/E development (high risk, moderate risk, low risk), scales of $\mathrm{I} / \mathrm{E}$, nursing initiations addressing the prevention and management of $\mathrm{I} / \mathrm{E}$, special antidotes, and subjects concerning wound care. The presentation was prepared based on the current literature including related topics and the subject was given as a lecture. In addition, the algorithm was prepared and printed as a poster. These posters were posted in the treatment rooms in children's clinics. Expert opinions were obtained from seven experts from the pediatric nursing department about the training content. The training content was reviewed and finalized accordingly.

\section{Data Collection Tools}

Introductory Form for Nurses: This form includes questions about the nurses' age, their education level, the clinics they worked in, their professional experience, previous education programs on $\mathrm{I} / \mathrm{E}$, and any previous encounters with I/E.
Pediatric Infiltration and Extravasation (PINE) Prevention and Management Information Form: This is a 20-question form with the options "True, False and Don't Know", which was created to determine the nurses' knowledge levels before and after the education program. In the form, eight questions (questions 2, 6, 7, 8, 12, 14, 18, and 20) should be responded to as "False" and 12 questions should be responded to as "True". The possible scores on the scale range from 0 to 20 . The questions in the form asked for descriptions of $I / E$, the fluids and medications that cause $I / E$, the interventions to prevent them, and the nursing interventions to be carried out after I/E development. The content validity of the form was ensured by consulting the opinions of seven experts. They were also asked to score each item from 1 to 4 ( 1 = Very Unsuitable, 4 = Completely Suitable). The Content Validity Index was used to evaluate expert opinions (18). The content validity index was 0.88 . This form is valid in Turkish. The form was reviewed and finalized accordingly.

The IV Insertion Site in the Pediatric Patient Evaluation Form: This form developed by researchers includes questions about age, gender, disease diagnosis, total patient days, date of IV catheter insertion day, IV fluid and medication therapy flowing through the IV catheter, IV insertion site and date and reason for removing the IV catheter. This form was used in the previous study (9).

The IV Insertion Site in Pediatric Patients with the I/E Evaluation Form: This form includes questions about the IV catheter insertion day and when I/E occurred, the localization of $I / E$, the time when the $I / E$ was noticed (time that passed since the I/E started), the infiltrated or extravasated IV fluid(s) and the medication therapy(s), and the applied interventions for I/E by the bedside nurses. This form was developed by the researchers and used in the previous study (9).

The Infusion Nurses Society Infiltration Scale: The scale which evaluates the I site was developed by The Infusion Nurses Society. It contains ratings on a scale from 0 to 4 as follows: Grade $0=$ No symptoms; Grade 1 = Skin blanched, edema $<1$ inch $(2.54 \mathrm{~cm})$; Grade 2 = Skin blanched, edema 1 to 6 inches (2.54 to $15.24 \mathrm{~cm}$ ); Grade 3 $=$ Skin blanched, gross edema $>6$ inches $(15.24 \mathrm{~cm})$, mild to moderate pain; Grade 4 = Skin blanched, bruised, swollen, gross edema $>6$ inches $(15.24 \mathrm{~cm})$ moderate to severe pain. The interrater reliability of the I scale was statistically significant $(k=0.393, p<0.001)(9,19,20)$. 
Extravasation Scale [National Cancer Institute Common Terminology Criteria for Adverse Events version 4.0 (NCI-TCAE) Classification]: This classification was made based on the NCI-CTCAE (21). It evaluates the E site by rating it on a scale from 0 to 5 (Grade $1=$ No symptoms; Grade 2 = Erythema with associated symptoms (e.g., edema, pain, induration, phlebitis); Grade $3=$ Ulceration or necrosis; severe tissue damage; operative intervention indicated; Grade 4 = Life-threatening consequences; urgent intervention indicated; Grade 5 = Death) $(9,21)$.

\section{Statistical Analysis}

The analysis of the study data was done using SPSS 16.0 software. The characteristics of the nurses were evaluated in numbers and percentages based on the information derived from the forms. The pre-test and post-test mean scores on the PINE Prevention and Management Information Form were evaluated using Fisher's exact test. The individual evaluation of the scale items before and after the education program was carried out using the McNemar test and Paired t-test. The study also calculated the I/E number for the total number of patient days to produce the I/E rate (I/E rate / patient days $\times 1,000$ days). The number of $\mathrm{I} / \mathrm{Es}$ in the previous study was compared to the findings in the pediatric I/E education program using a chi-square test. The researchers also calculated the odds ratio between the incidences in the previous study and this education program (9).

\section{Results}

Participant Characteristics: The average age of the nurses in this study was $29.89 \pm 7.69$ years [minimum (min): 21, maximum (max): 50)]. Of the nurses, $49.4 \%$ had encountered I/E before, whereas $89.9 \%$ had never received any education program on $\mathrm{I} / \mathrm{E}$ and $55.7 \%$ did not evaluate I/E as a medical error. Of the patients; $20 \%$ were 1 to 20 months old, and $20 \%$ were aged 6 to12 years; $57.3 \%$ were females; $24.7 \%$ were in the general pediatrics service, and

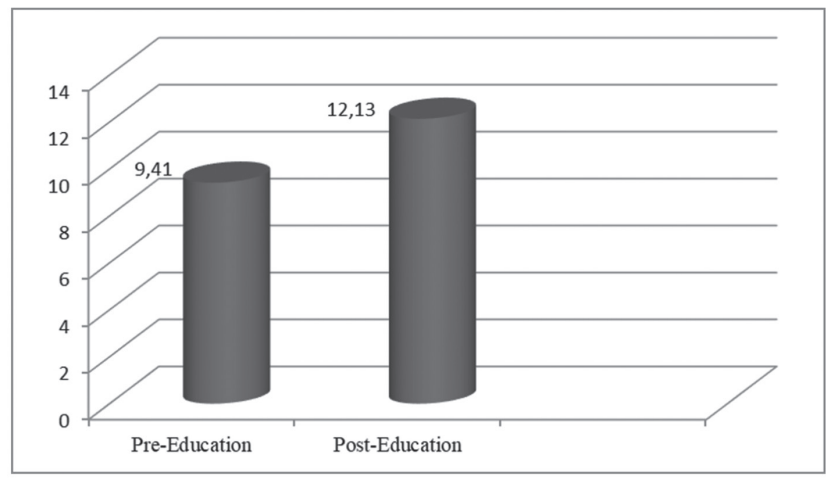

Figure 1. The knowledge level of nurses
$50.7 \%$ were monitored with one catheter (Table I). Before the education program, the knowledge mean score of the nurses was $9.41 \pm 3.22$ (min: 0 , max: 17), and $12.13 \pm 1.58$ (min: 8, max: 16) after the education program. The increase in the knowledge level stimulated by the education was statistically significant (t: 7,328; $p<0.001$ ) (Figure 1).

IV Infiltration and Extravasation Rates: In $48.8 \%$ of the patients, the catheter was removed due to a blockage (Table II). In the PINE education program, the number of catheter days was 1,221, and the I/E rate in 289 IV catheter initiations was 0.8. A statistically significant difference was found between the I/E numbers in the previous study and in

\begin{tabular}{|c|c|c|c|}
\hline \multicolumn{2}{|c|}{ Nurse characteristics } & $\mathbf{n}$ & $\%$ \\
\hline \multicolumn{2}{|l|}{ Age } & \multicolumn{2}{|c|}{$\begin{array}{l}29.89 \pm 7.69 \\
\text { (min: } 21 \\
\text { max: } 50)\end{array}$} \\
\hline $\begin{array}{l}\text { Years of } \\
\text { study } \\
\text { in child } \\
\text { wards/ } \\
\text { units }\end{array}$ & $\begin{array}{l}0-1 \text { year } \\
1-5 \text { year } \\
6-10 \text { year } \\
11-15 \text { year } \\
\geq 16 \text { year }\end{array}$ & $\begin{array}{l}29 \\
23 \\
14 \\
5 \\
8\end{array}$ & $\begin{array}{l}36.7 \\
29.1 \\
17.7 \\
6.3 \\
10.1\end{array}$ \\
\hline $\begin{array}{l}\text { Wards/ } \\
\text { units }\end{array}$ & $\begin{array}{l}\mathrm{PICU}+\mathrm{NICU} \\
\text { Oncology/Hematology } \\
\text { General Pediatric } \\
\text { Other Clinics (Neurology, Nephrology, } \\
\text { Cardiology, Respiratory) }\end{array}$ & $\begin{array}{l}12 \\
28 \\
18 \\
23\end{array}$ & $\begin{array}{l}12.7 \\
35.4 \\
22.8 \\
29.1\end{array}$ \\
\hline \multicolumn{2}{|l|}{ Total } & 79 & 100 \\
\hline \multicolumn{2}{|c|}{ Patient Characteristics } & $\mathbf{n}$ & $\%$ \\
\hline Age & $\begin{array}{l}\text { Neonatal } \\
\text { Infant ( } 1-12 \text { months) } \\
1-3 \text { years } \\
3-6 \text { years } \\
6-12 \text { years } \\
12 \text { years and older }\end{array}$ & $\begin{array}{l}22 \\
30 \\
18 \\
31 \\
30 \\
19\end{array}$ & $\begin{array}{l}14.7 \\
20.0 \\
12.0 \\
20.7 \\
20.0 \\
12.7\end{array}$ \\
\hline Gender & $\begin{array}{l}\text { Male } \\
\text { Female }\end{array}$ & $\begin{array}{l}86 \\
64\end{array}$ & $\begin{array}{l}57.3 \\
42.7\end{array}$ \\
\hline $\begin{array}{l}\text { Patients' } \\
\text { ward/unit }\end{array}$ & $\begin{array}{l}\text { NICU } \\
\text { PICU } \\
\text { Neurology } \\
\text { Nephrology } \\
\text { Cardiology } \\
\text { Respiratory } \\
\text { General Pediatric } \\
\text { Oncology/Hematology }\end{array}$ & $\begin{array}{l}18 \\
15 \\
20 \\
10 \\
10 \\
18 \\
37 \\
22\end{array}$ & $\begin{array}{l}12 \\
10 \\
13.4 \\
6.6 \\
6.6 \\
12 \\
24.7 \\
14.7\end{array}$ \\
\hline \multicolumn{2}{|l|}{ Total } & 150 & 100 \\
\hline
\end{tabular}




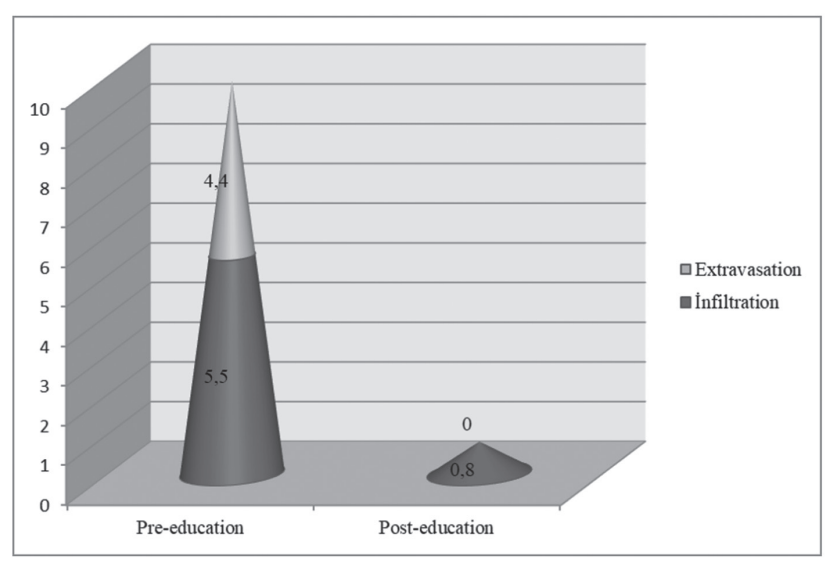

Figure 2. Extravasation and infiltration rates

\begin{tabular}{|c|c|c|}
\hline \multicolumn{2}{|c|}{ Catheter Characteristics } & $\begin{array}{l}\begin{array}{l}\text { Post- } \\
\text { education }\end{array} \\
\mathrm{n}(\%)\end{array}$ \\
\hline $\begin{array}{l}\text { The site of the } \\
\text { peripheral IV line }\end{array}$ & $\begin{array}{l}\text { Left } \\
\text { Right }\end{array}$ & $\begin{array}{l}172(59.5) \\
117(40.5)\end{array}$ \\
\hline $\begin{array}{l}\text { Inserted in } \\
\text { peripheral vein }\end{array}$ & $\begin{array}{l}\text { Dorsal metacarpal } \\
\text { Brachial } \\
\text { Vena marginalis medialis } \\
\text { Cephalic } \\
\text { Cephal } \\
\text { Radial } \\
\text { Vena temporalis } \\
\text { Femoral } \\
\text { Antecubital }\end{array}$ & $\begin{array}{l}146(50.5) \\
79(27.3) \\
10(3.5) \\
15(5.2) \\
18(6.2) \\
3(1.0) \\
9(3.1) \\
1(0.3) \\
8(2.8) \\
\end{array}$ \\
\hline $\begin{array}{l}\text { The reason for } \\
\text { catheter removal }\end{array}$ & $\begin{array}{l}\text { Obstruction } \\
\text { The end of treatment } \\
\text { Dislocation } \\
\text { Infiltration/Extravasation }\end{array}$ & $\begin{array}{l}141(48.8) \\
112(38.8) \\
35(12.1) \\
1(0.3)\end{array}$ \\
\hline \multicolumn{2}{|l|}{ Total } & $289(100)$ \\
\hline
\end{tabular}

this education program $\left(\chi^{2}: 9,234 ; p=0.002\right)$ (Table III, Figure 2). The education program was implemented based on the probability rate that was calculated by the researchers; this enabled a reduction of pediatric I/E by 12 -fold (odds ratio: $12.214,95 \%$ confidence interval).

After the education program, there was a Grade $2 \mathrm{I}$ in only one patient. That I developed in a two-month-old male patient who was being monitored in the general pediatrics service with a diagnosis of urinary tract infection in the right dorsal metacarpal vein and receiving a 5\% Dextrose+0.9\% $\mathrm{NaCl}$ fluid treatment during the second day of the catheter. The I was recognized 15 minutes after its development. Subsequently, the fluid treatment was ceased, physiological saline solution washing was applied after a fluid aspiration, and the extremity was elevated.
Table III. Infiltration and extravasation incidence rate between pre-education and post-education

\begin{tabular}{|c|c|c|c|}
\hline Variables & $\begin{array}{l}\text { Pre- } \\
\text { education }\end{array}$ & $\begin{array}{l}\text { Post- } \\
\text { education }\end{array}$ & \\
\hline Total catheter days & 908 & 1,221 & \\
\hline $\begin{array}{l}\text { Number of intravenous } \\
\text { catheter insertions }\end{array}$ & 297 & 289 & \\
\hline \multicolumn{4}{|c|}{ Number of infiltrations and extravasations } \\
\hline $\begin{array}{l}\text { - Number of infiltrations } \\
\text { - Number of extravasations }\end{array}$ & $\begin{array}{l}5 \\
4\end{array}$ & $\begin{array}{l}1 \\
0\end{array}$ & $X^{2}:$ \\
\hline $\begin{array}{l}\text { Infiltration and extravasation } \\
\text { incidence rate } \\
\text { - Infiltration incidence rate } \\
\text { - Extravasation incidence rate }\end{array}$ & $\begin{array}{l}9.9 \\
5.5 \\
4.4\end{array}$ & $\begin{array}{l}0.8 \\
0.8 \\
0\end{array}$ & $\begin{array}{l}9,234 \\
\text { p: } \\
0.002\end{array}$ \\
\hline \multirow[t]{3}{*}{ Odds ratio } & \multirow[t]{3}{*}{12.214} & \multicolumn{2}{|c|}{$\begin{array}{l}95 \% \text { confidence } \\
\text { interval }\end{array}$} \\
\hline & & Lower & Upper \\
\hline & & 1,545 & 96,576 \\
\hline
\end{tabular}

\section{Discussion}

Several researchers have emphasized that the education of nurses is one of the most effective ways to prevent I/E in hospitalized children $(2,13,16,22)$. In the present education program, the nurses improved their knowledge about pediatric I/E management and increased their rates of correct response to most of the statements. Similarly, the study by Taylor (2) evaluated the efficiency of education on evidence-based studies of the prevention of $I$ and found that there was a significant difference in the knowledge scores before and after the education, proving that the education increased the information level of the participants. Tofani et al. (13) stressed that compulsory education given to nurses using a touch-look-compare method to reduce pediatric I/E rates led to an improvement in team communication and systematic recovery. Another relevant study stated that algorithms developed to prevent pediatric E's contributed to the prevision of nursing care and helped rapid and effective intervention in E incidents (16).

A review of the relevant literature indicated that there has been an increased number of studies in recent years on the effectiveness of the initiation of education in pediatric I: the I/E rates examined in these studies were high, and there was an obvious reduction in these I/E rates thanks to these initiations or the education provided to the nurses $(2,13,23,24)$. In this education program, the rates of pediatric I/E were reduced 12-fold. In the study by Taylor (2), the rate of I in 1,000 patient days was 20.00 before the education, 11.83 after the education, and 8.93 at the end of the education program. In the study by Paquette et al. (11), 42 patients had 
documented $E$ and the incidence of $E$ was $0.04 \%$ for every patient day. Tofani et al. (13) evaluated the PIV initiation area using a touch-look-compare method at the beginning of every hour and found that the I/E rate was reduced from 4.2 to 1.8 per 1,000 patient-days. The present study is based on that study and similar studies for the development of PINE education programs; it led to an important reduction in the I/E rate as in those other studies.

In the present study, the interventions applied to the patients with I/E before the study were not sufficient, and none of the patients had an antidote (9). After the study, only one patient received a correct I intervention. There was no administration of hyaluronidase to any of the patients either before or after the education. In the study by Paquette et al. (11), 50\% of the subjects with $E$ were treated using the correct antidote. In that study, $81 \%$ of the participants needed an antidote; however, only $33 \%$ of them were provided with that treatment.

In this study, catheter obstruction was the leading cause of catheter removal. The relevant literature also indicates that catheter obstruction is one of the most common catheter-related complications; it is key in order to maintain IV usage to give bolus flushing fluid to the patient and to make a safe determination (17).

\section{Study Limitations}

The present study aimed to prevent and manage pediatric I/E. This study also developed nursing practices and reduced rates of I/E. Some limitations of the study need to be taken into consideration. First, only $66 \%$ of the nurses working in the hospital where the study was carried out participated in the study. Another limitation of this study was that the patients were only monitored for six months after the education about I/E. These factors limit the generalization of the study results.

\section{Conclusion}

Pediatric I/E is common among children who are inpatients in health institutions because of acute and/ or chronic health problems. This study has shown that a pediatric I/E education program improved nurses' knowledge about I/E management, and reduced I/E rates as well. This situation led to an improvement in nursing care and the quality of patient care and helped progress toward increased patient safety. It is recommended that prevention of I/E should become standard practice, institutional policy should be regulated to ensure appropriate treatment and care after injury has occurred and that in-service education to ensure that the information received about I/E should be up to date and lasting and all health personnel should be aware of this issue.

\section{Acknowledgements}

We acknowledge the financial support of the Ege University Scientific Research Projects Directorate (project grant number: 2015-HYO-003).

\section{Ethics}

Ethics Committee Approval: Scientific Ethics Committee of a Faculty of Nursing approved this study (IRB number: 2015-93, approval date: 31.08.2015) and Children's Hospital, where the research was carried out.

Informed Consent: Children and their families were informed about the study and written informed consent was obtained. Also the nurses who participate in pediatric infiltration and extravasation education program have given written consent.

Peer-review: Enternally peer-reviewed.

\section{Authorship Contributions}

Surgical and Medical Practices: A.K., G.Ö.G., F.Y., Concept: A.K., G.Ö.G., F.Y., Design: A.K., G.Ö.G., F.Y., Data Collection or Processing: E.B., Ş.B.Y., H.N.Ç.Ö., A.Kar., D.Z., S.A.S., M.G., Analysis or Interpretation: A.K., G.Ö.G., F.Y., Literature Search: A.K., G.Ö.G., F.Y., Writing: A.K., D.Z.B.

Conflict of Interest: None of the authors had conflict of interest.

Financial Disclosure: The authors declared that this study received no financial support.

\section{References}

1. Doellman D, Hadaway L, Bowe-Geddes LA, et al. Infiltration and extravasation: update on prevention and management. Journal of Infusion Nursing 2009; 32:203-11.

2. Taylor JT. Implementing an evidence-based practice project in the prevention of peripheral intravenous site infiltrations in children. Journal of Infusion Nursing 2015; 38:430-5.

3. Amjad I, Murphy T, Nylander-Housholder L, Ranft A. A new approach to management of intravenous infiltration in pediatric patients: pathophysiology, classification, and treatment. Journal of Infusion Nursing 2011; 34:242-9.

4. Yan $\mathrm{YM}$, Gong $\mathrm{M}$, Chen $\mathrm{L}$, et al. Incidence, risk factors and treatment outcomes of drug extravasation in pediatric patients in China. Turk J Pediatr 2017; 59:1621-168.

5. Tripi PA, Thomas S, Clebone A, Goldfinger MM, Tobias ID. Peripheral intravenous catheter problems in infants and children presenting for anesthesia and surgery. Middle East Journal of Anaesthesiol 2016; 23:411-4.

6. Wilkins CE, Emmerson AJB. Extravasation injuries on regional neonatal units. Archives of Disease in Childhood. Fetal and Neonatal Edition 2004; 89:274-5. 
7. Temizsoy E, Eriş Ö, Karakoç A, Cangur \$̧, Karatekin G, Ovalı F. Pediatrik Periferal İntravenöz İnfiltrasyon Ölçeğinin Türkçe Geçerlilik Güvenirliği ve Yenidoğana Uyarlanması. Journal of Pediatric Research 2017; 4:232-8.

8. Atay S, Sen S, Çukurlu D. Incidence of infiltration/extravasation in newborns using peripheral venous catheter and affecting factors. Revista da Escola de Enfermagem da USP 2018; 52:03360.

9. Gerçeker GÖ, Kahraman A, Yardımcı F, et al. Infiltration and extravasation in pediatric patients: a prevalence study in a children's hospital. Journal of Vascular Access 2018; 19:266-271.

10. Gopalakrishnan PN, Goel N, Banerjee S. Saline irrigation for the management of skin extravasation injury in neonates. Cochrane Database Systematic Reviews 2012; 15:CD008404.

11. Paquette V, McGloin R, Northway T, DeZorzi P, Singh A, Carr R. Describing intravenous extravasation in children (DIVE study). The Canadian Journal of Hospital Pharmacy 2011; 64:340-5.

12. Kuensting LL. Treatment of intravenous infiltration in a neonate. Journal of Pediatric Health Care 2010; 24:184-8.

13. Tofani BF, Rineair SA, Gosdin CH, et al. Quality improvement project to reduce infiltration and extravasation events in a pediatric hospital. Journal Pediatric Nursing 2012; 27:682-9.

14. Dougherty L. IV therapy: recognizing the differences between infiltration and extravasation. British Journal of Nursing (Mark Allen Publishing) 2008; 17:898-901.

15. Martin CD, Thompson DR. Study Sample Size Calculation. Design and Analysis of Clinical Nursing Reseach Studies. London, Routledge, 2000.

16. Chanes DC, da Luz Gonçalves Pedreira M, de Gutiérrez MGR. Antineoplastic agents extravasation from peripheral intravenous line in children: a simple strategy for a safer nursing care. European Journal of Oncology Nursing 2012; 16:17-25.

17. Hetzler RA, Wilson M, Hill EK, Hollenback C. Securing pediatric peripheral iv catheters-application of an evidence-based practice model. Journal of Pediatric Nursing 2011; 26:143-8.

18. Polit $\mathrm{D}$, Beck $C$. The content validity index: are you sure you know what's being reported? critique and recommendations. Research in Nursing Health 2006; 29:489-97.

19. Groll D, Davies B, Mac Donald J, Nelson S, Virani T. Evaluation of the psychometric properties of the phlebitis and infiltration scales for the assessment of complications of peripheral vascular access devices. Journal of Infusion Nursing 2010; 33:385-90.

20. Infusion Nurses Society. Infusion nursing standards of practice. Journal of Infusion Nursing 2006; 29(1 Suppl):S1-92.

21. National Cancer Institute. Common Terminology Criteria for Adverse Events (CTCAE) Common Terminology Criteria for Adverse Events v4.0 (CTCAE). Retrieved June 20, 2016,

22. Panghal A, Naranje KM, Singh A, Pandita A, Gupta G. Reducing infiltration rates of peripheral intravenous cannula: A quality improvement initiative in a neonatal intensive care unit of tertiary care hospital in Northern India. Indian I Child Health $2019 ; 6: 205-8$.

23. Major TW, Huey TK. Decreasing IV infiltrates in the pediatric patient-system-based improvement project. Pediatric Nursing 2016; 42:14-20.

24. Park SM, Jeong IS, Kim KL, Park KJ, Jung MJ, Jun SS. The effect of intravenous infiltration management program for hospitalized children. Journal of Pediatric Nursing 2016; 31:172-8. 